\title{
PREVALENCE OF CHRONIC SUPPURATIVE OTITIS MEDIA IN SCHOOL GOING CHILDREN OF PATIALA DISTRICT OF PUNJAB, INDIA
}

\author{
Imrinder Kaur ${ }^{1}$, J. P. Goyal2, Dalbir Singh ${ }^{3}$
}

1 Junior Resident, Department of ENT, Government Medical College, Patiala.

${ }^{2}$ Assistant Professor, Department of ENT, Government Medical College, Patiala.

${ }^{3}$ Associate Professor, Department of ENT Government Medical College, Patiala.

\section{ABSTRACT}

\section{BACKGROUND}

Otitis media is an inflammation of the middle ear cleft. It is known to be one of the most common childhood infections. Children from developing countries having unfavourable environment witness an extraordinary high incidence of severe episodes of otitis media.

The objective of the study is to determine the prevalence of chronic suppurative otitis media (CSOM) in schoolchildren of Patiala district.

\section{MATERIALS AND METHODS}

A simple random sampling method was used to obtain the selected sample size of 1224 children from one urban and three rural government schools of adjacent villages of Patiala district of Punjab, India.

\section{RESULTS}

The children were aged 5-15 years. The prevalence rate of CSOM was found to be $1.41 \%$ in the urban schoolchildren and $5.45 \%$ in the rural schoolchildren. The difference was statistically significant. Unilateral disease was found to be most prevalent (78.95\%). Of the studied cases, $86.84 \%$ had tubotympanic disease. Active disease was observed in $36.8 \%$ of the cases.

\section{CONCLUSION}

It can be said that CSOM is still an important cause of morbidity. This study shows that the prevalence of CSOM is higher in rural schoolchildren than that in urban schoolchildren. Health education, improvement in socioeconomic status and healthcare facilities is required to reduce the prevalence and prevent disability among schoolchildren.

\section{KEYWORDS}

Chronic Suppurative Otitis Media, Prevalence, School Going Children, Punjab.

HOW TO CITE THIS ARTICLE: Kaur I, Goyal JP, Singh D. Prevalence of chronic suppurative otitis media in school going children of Patiala district of Punjab, India. J. Evolution Med. Dent. Sci. 2017;6(75):5402-5407, DOI: 10.14260/Jemds/2017/1171

\section{BACKGROUND}

Otitis media is an inflammation of the middle ear cleft with or without intact tympanic membrane. It is known to be one of the most common childhood infections and a leading reason for antibiotic prescriptions in the developed world. It was first described by Hippocrates as early as 450 B.C. and continues to present itself even today as one of the most perplexing universally observed medical problems of childhood and a leading cause of hearing loss.[1] It can present itself in different forms because of large variations in the nature of the disease. According to a WHO survey, 42 million people ( $>3$ years) worldwide have hearing loss. The major cause for hearing impairment is otitis media, which is second only to common cold as a cause of infection in childhood.[2] It is estimated that about $90 \%$ of the children have at least one episode of otitis media by their second birthday. For children less than 15 years, the most frequent diagnosis made in clinical practice is otitis media. ${ }^{[3]}$ Children from developing

Financial or Other, Competing Interest: None.

Submission 02-08-2017, Peer Review 08-09-2017,

Acceptance 12-09-2017, Published 18-09-2017.

Corresponding Author:

Dr. J. P. Goyal,

D-10 Medical Campus Rajindra Hospital,

Patiala.

E-mail:imrinder@hotmail.com

DOI: $10.14260 /$ jemds $/ 2017 / 1171$ countries having unfavourable environment witness an extraordinary high incidence of severe episodes of otitis media (Frequent perforation of tympanic membrane with persistent suppurative discharge and necrotising process in the middle ear). Children from lower socioeconomic groups being more vulnerable to otitis media have to be given special care to prevent hearing retardation.[4] If acute otitis media is verbally contrasted with chronic otitis media, the differential emphasis falls on the word chronic, which carries an implication of time and is generally taken to mean 'longstanding'. It would be accurate to use the words rapid and slow as synonyms for acute and chronic otitis media with the reservation that the words correctly qualify the rate of pathological changes taking place but not necessarily the clinical mode of presentation.[5] CSOM is defined by the WHO as "a stage of ear disease in which there is chronic infection of the middle ear cleft, i.e. Eustachian tube, middle ear and mastoid, and in which a non-intact tympanic membrane (e.g. perforation or tympanostomy tube) and discharge (Otorrhoea) are present."[6]

Chronic suppurative otitis media is also one of the most common ear diseases found in India. In India, it is the most important cause of deafness and takes a considerable amount of clinical and operative time of otolaryngologists. Though imminently preventable, the progression from a benign upper respiratory infection (URI) to an acute otitis media with perforation and recurring/persistent infection (CSOM) leading ultimately to hearing loss is depressingly quite 
common in rural areas of India.[7] The aetiology and pathogenesis of otitis media are multifactorial and include genetic factors, infections, allergy, environmental exposure, social and racial factors, and Eustachian tube dysfunction. During the recent decades, the incidence of CSOM has sharply declined due to improvements in housing, hygiene and antimicrobial chemotherapy. Still ignorance, poverty, and traditional beliefs are the major risk factors for not attending hospitals. The high prevalence of CSOM in general population and more so in schoolchildren all over the world has led us to undertake a study because proper hospital facilities, proper nutritious diet, and proper medical care are far from adequate, especially in rural areas, in our and other developing countries.

\section{MATERIALS AND METHODS}

This study was conducted in one urban and three rural government schools of Patiala district during the time period 2008 to 2011. For this study, there were 711 children from urban school and 513 children from rural schools. Altogether, there were 1224 schoolchildren aged between 5 and 15 years. Purposive method of sampling was used to obtain the selected sample.

The diagnosis of CSOM was made based on the history and otoscopic findings. Children with CSOM were referred to the ENT OPD at Govt. Medical College and at Rajindra Hospital, Patiala, for a detailed ENT examination. Data were analysed statistically using frequency and percentage.

All data were analysed using IBM Statistical Package for the Social Sciences (SPSS) version 20.0. The qualitative data were expressed as number with percentage and chi-square test was used for analysis. $\mathrm{P}$ value at $<0.05$ was considered significant and at $<0.01$ was considered highly significant, while $>0.05$ was considered not significant.

\section{Study Design}

Survey study.

\section{Study Period}

Three years.

\section{Sampling}

Patiala district was selected for the purpose of study. For this study, one urban and three rural government schools of Patiala district during the time period 2008 to 2011 were selected.

\section{Study Method}

For this study, there were 711 children from urban school and 513 children from rural schools, those attending medical camps organised by the Rajindra Hospital, Patiala. All these children were interviewed and examined. Altogether, there were 1224 schoolchildren aged between 5 and 15 years. Children with CSOM were referred to ENT OPD at Govt. Medical and Rajindra Hospital, Patiala for detailed ENT examination.

\section{Sample Size}

1224 presented in camps.

\section{Inclusion Criteria}

1. Patients aged 5 to 15 years are taken for the study.

2. Patients of both sexes.
3. Patients were based on information provided by the class teacher or school authorities of the respective schools.

\section{Exclusion Criteria}

1. Patients aged $<5$ years and $>15$ years and who did not consent to be the part of study.

2. Patients with any other medical problem.

\section{Ethical}

The study was approved by the institutional research committee and ethics committee of Govt. Medical and Rajindra Hospital, Patiala, Punjab. India.

\section{RESULTS}

In this cross-sectional study, 711 students (405 male, 306 female) were examined in urban school and 513 students (311 male, 202 female) were examined in rural schools.

Majority of the children $(47.12 \%)$ in the urban school belonged to age group of 13-15 years whereas those $(34.70 \%)$ in the rural school belonged to age group of 9-12 years (Table 1).

A total of 38 students were found to have CSOM. Of the 711 students examined in the urban school, CSOM was present in 10 students (1.41\%) whereas in the rural schools, it was found to be present in 28 of 513 children examined (5.46\%). So, the prevalence of CSOM was found to be higher in rural schoolchildren compared to the urban schoolchildren (Table 2). Of the 38 cases, majority of the cases belonged to age group of $5-8$ years (39.47\%).

The socioeconomic status was calculated according to the modified Kuppuswamy's socioeconomic status scale proposed by Government of India, which takes into account education, occupation, and income. Majority of the cases belonged to upper-lower (42.10\%) and lower-middle $(31.57 \%)$ class families.

In our study, CSOM cases in rural areas showed discharge for more than 3 months but it was less than 1 year in $17.86 \%$ children. Discharge durations of 1 year, 2 years, 3 years, and more than 3 years were observed in $17.86 \%, 28.57 \%$, $10.71 \%$, and $25 \%$ cases, respectively. In the urban group, $50 \%$ cases had a history of ear discharge for 2 years whereas $30 \%$ cases had a history of discharge for 1 year and $20 \%$ for 3 years (Table 3).

Of the 38 cases, 30 (78.95\%) had unilateral and 8 $(21.05 \%)$ had bilateral involvement. Active disease was present in 14 cases $(36.84 \%)$ whereas 24 cases $(63.16 \%)$ had inactive disease.

In the case of tubotympanic CSOM, the involvement of the right-sided ears was higher whereas in the case of atticoantral-type CSOM, the involvement was equal on both the sides (Table 4). Of 46 ears with CSOM, inferior and subtotal perforations were found in 13 (28.26\%) and 11 (23.91\%) ears, respectively, followed by anterior inferior quadrant perforations $(15.22 \%)$. The tympanic membrane perforations were of varying shape such as round $(58.70 \%)$, oval (15.22\%), and kidney (23.91\%).

Of 46 cases of perforation, $15.22 \%$ had normal hearing, $71.74 \%$ had conductive deafness, and $2.17 \%$ had sensorineural type of hearing loss. In 5 (10.87\%) cases, tuning fork tests could not be conducted as the children were from younger age group and were unable to appreciate the test. On pure tone audiometry testing, 38 cases $(82.60 \%)$ had 
conductive hearing loss whereas 3 cases $(6.52 \%)$ had mixed hearing loss and 2 cases $(2.17 \%)$ had sensorineural hearing loss whereas 4 cases $(8.70 \%)$ had hearing within normal range.

Major sociodemographic risk factors observed were lower socioeconomic status (57.90\%), smoking habits of the father (42.10\%), and indoor cooking with kerosene (36.84\%) (Table 5). Major clinical risk factors associated were malnutrition followed by URI, chronic tonsillitis, and adenoid hypertrophy (Table 6).

\begin{tabular}{|c|c|c|c|c|c|}
\hline \multirow{2}{*}{$\begin{array}{c}\text { Age } \\
(\text { Years) }\end{array}$} & \multicolumn{2}{|c|}{$\begin{array}{c}\text { No. of Students in } \\
\text { Urban School }\end{array}$} & \multicolumn{2}{|c|}{$\begin{array}{c}\text { No. of Students in } \\
\text { Rural School }\end{array}$} & \multirow{2}{*}{$\begin{array}{c}\text { Value } \\
\left(X^{2}\right)\end{array}$} \\
\cline { 2 - 5 } & No. & \% Age & No. & \% Age & \\
\hline $5-8$ & 120 & 16.88 & 167 & 32.55 & $\begin{array}{c}0.349 \\
(0.88)\end{array}$ \\
\hline $9-12$ & 256 & 36.00 & 178 & 34.70 & $\begin{array}{c}0.038 \\
(92.90)\end{array}$ \\
\hline $413-15$ & 335 & 47.12 & 168 & 32.75 & $\begin{array}{c}0.022 \\
(6.98)\end{array}$ \\
\hline Total & $\mathbf{7 1 1}$ & $\mathbf{1 0 0}$ & $\mathbf{5 1 3}$ & $\mathbf{1 0 0}$ & $\begin{array}{c}\mathbf{0 . 0 3 2} \\
\mathbf{( 4 . 5 9 )}\end{array}$ \\
\hline $\begin{array}{c}\text { P value } \\
\left(\mathrm{X}^{2}\right)\end{array}$ & \multicolumn{6}{|c|}{0.021 (11.09) } \\
\hline \multicolumn{7}{|c|}{ Table 1. Distribution of Children by Age } \\
\hline
\end{tabular}

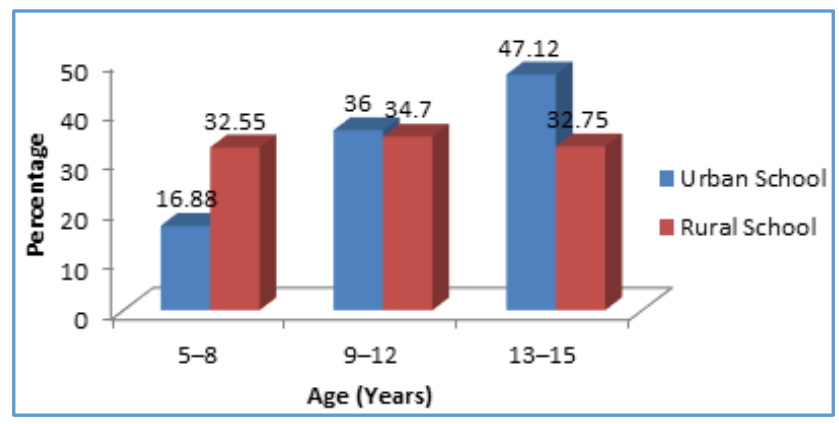

\begin{tabular}{|c|c|c|c|c|c|c|}
\hline \multirow{2}{*}{ CSOM } & \multicolumn{2}{|c|}{$\begin{array}{c}\text { Students in } \\
\text { Urban School }\end{array}$} & \multicolumn{2}{c|}{$\begin{array}{c}\text { Students in } \\
\text { Rural School }\end{array}$} & \multicolumn{2}{|c|}{ Total } \\
\cline { 2 - 7 } & No. & \% Age & No. & \% Age & No. & \% Age \\
\hline Present & 10 & 1.41 & 28 & 5.46 & 38 & 3.10 \\
\hline Absent & 701 & 98.59 & 485 & 94.54 & 1186 & 96.90 \\
\hline Total & $\mathbf{7 1 1}$ & $\mathbf{1 0 0}$ & $\mathbf{5 1 3}$ & $\mathbf{1 0 0}$ & $\mathbf{1 2 2 4}$ & $\mathbf{1 0 0}$ \\
\hline $\begin{array}{c}\text { P Vale } \\
\left(\mathrm{X}^{2}\right)\end{array}$ & \multicolumn{7}{|c|}{$001(14.94)$} \\
\hline \multicolumn{7}{|c|}{ Table 2. Distribution of Children by CSOM } \\
\hline
\end{tabular}

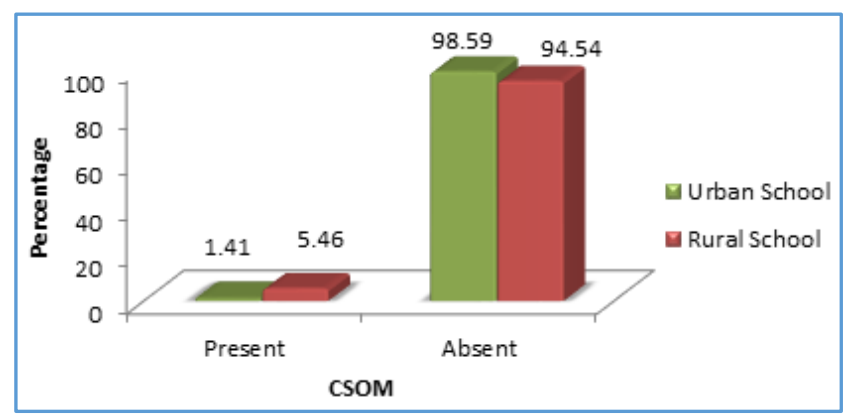

\begin{tabular}{|c|c|c|c|c|c|c|c|}
\hline \multirow{2}{*}{$\begin{array}{c}\text { Duration } \\
\text { (years) }\end{array}$} & $\begin{array}{c}\text { Students in } \\
\text { Urban } \\
\text { School }\end{array}$ & $\begin{array}{c}\text { Students in } \\
\text { Rural } \\
\text { School }\end{array}$ & \multicolumn{2}{|c|}{ Total } & $\begin{array}{c}\text { P } \\
\text { value } \\
\left(X^{2}\right)\end{array}$ \\
\cline { 2 - 7 } & No. & $\%$ Age & No. & $\%$ Age & No. & $\%$ Age & \\
\hline $\begin{array}{c}>3 \\
\text { months to } \\
<1 \text { year }\end{array}$ & - & - & 5 & 17.86 & 5 & 13.16 & $\begin{array}{c}1.00 \\
(0.00)\end{array}$ \\
\hline 1 year & 3 & 30 & 5 & 17.86 & 8 & 21.05 & $\begin{array}{c}0.183 \\
(1.77)\end{array}$ \\
\hline 2 years & 5 & 50 & 8 & 28.57 & 13 & 34.21 & $\begin{array}{c}0.027 \\
(15.56)\end{array}$ \\
\hline 3 years & 2 & 20 & 3 & 10.71 & 5 & 13.16 & $\begin{array}{c}0.297 \\
(1.09)\end{array}$ \\
\hline$>3$ years & - & - & 7 & 25 & 7 & 18.42 & $\begin{array}{c}1.00 \\
(0.00)\end{array}$ \\
\hline Total & $\mathbf{1 0}$ & $\mathbf{1 0 0}$ & $\mathbf{2 8}$ & $\mathbf{1 0 0}$ & $\mathbf{3 8}$ & $\mathbf{1 0 0}$ & $\begin{array}{c}\mathbf{0 . 0 1 2} \\
(\mathbf{6 . 2 8})\end{array}$ \\
\hline $\begin{array}{c}\text { p value } \\
\left(X^{2}\right)\end{array}$ & \multicolumn{7}{|c|}{$0.046(15.96)$} \\
\hline \multicolumn{7}{|c|}{ Table 3. Duration of Ear Discharge } \\
\hline
\end{tabular}

\begin{tabular}{|c|c|c|c|c|c|c|c|}
\hline \multirow[t]{2}{*}{ CSOM } & \multicolumn{2}{|c|}{$\begin{array}{c}\text { Students in } \\
\text { Urban } \\
\text { School } \\
\end{array}$} & \multicolumn{2}{|c|}{$\begin{array}{c}\text { Students in } \\
\text { Rural } \\
\text { School } \\
\end{array}$} & \multicolumn{2}{|c|}{ Total } & \multirow[t]{2}{*}{$\begin{array}{c}p \text { value } \\
\left(X^{2}\right)\end{array}$} \\
\hline & No. & $\%$ Age & No. & $\%$ Age & No. & $\%$ Age & \\
\hline \multicolumn{8}{|c|}{ Tubotympanic } \\
\hline Right & 4 & 40 & 11 & 39.29 & 15 & 39.47 & $\begin{array}{c}0.001 \\
(15.37)\end{array}$ \\
\hline Left & 3 & 30 & 8 & 28.57 & 11 & 28.95 & $\begin{array}{l}0.133 \\
(2.07)\end{array}$ \\
\hline Both & 2 & 20 & 5 & 17.86 & 7 & 18.42 & $\begin{array}{l}0.242 \\
(1.37)\end{array}$ \\
\hline Total & 9 & 90 & 24 & 85.72 & 33 & 86.84 & $\begin{array}{l}0.012 \\
(6.35)\end{array}$ \\
\hline \multicolumn{8}{|c|}{ Atticoantral } \\
\hline Right & 1 & 10 & 1 & 3.57 & 2 & 5.26 & $\begin{array}{c}0.541 \\
(0.37)\end{array}$ \\
\hline Left & - & - & 2 & 7.14 & 2 & 5.26 & $\begin{array}{c}1.00 \\
(0.00)\end{array}$ \\
\hline Both & - & - & 1 & 3.57 & 1 & 2.63 & $\begin{array}{c}1.00 \\
(0.00)\end{array}$ \\
\hline Total & 1 & 10 & 4 & 14.28 & 5 & 13.16 & $\begin{array}{l}0.367 \\
(0.83)\end{array}$ \\
\hline Total & 10 & 100 & 28 & 100 & 38 & 100 & $\begin{array}{l}0.012 \\
(7.21)\end{array}$ \\
\hline \multicolumn{8}{|c|}{ Table 4. Type and side of CSOM } \\
\hline
\end{tabular}
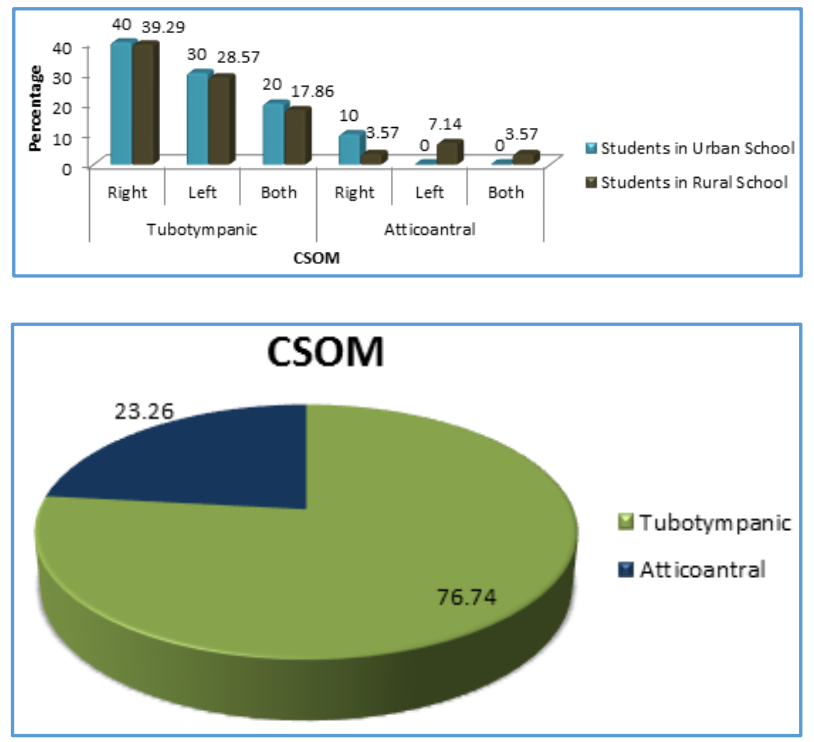


\begin{tabular}{|c|c|c|}
\hline Associated Factors & No. of Cases & $\%$ Age \\
\hline Lower social class & 22 & 57.90 \\
\hline $\begin{array}{l}\text { Live in congested houses } \\
\qquad(>10 \text { people })\end{array}$ & 10 & 26.31 \\
\hline Families with $>5$ children & 6 & 15.79 \\
\hline Indoor cooking & 14 & 36.84 \\
\hline Bottle feeding & 9 & 23.68 \\
\hline Smoking father & 16 & 42.10 \\
\hline $\begin{array}{c}\text { Early onset of disease }<1 \\
\text { year }\end{array}$ & 7 & 18.42 \\
\hline $\begin{array}{l}\text { Family history of ear } \\
\text { discharge }\end{array}$ & 12 & 31.58 \\
\hline Illiterate mother & 8 & 21.05 \\
\hline $\begin{array}{l}\text { Unhygienic ear-cleaning } \\
\text { practices }\end{array}$ & 13 & 34.21 \\
\hline \multicolumn{3}{|c|}{$\begin{array}{l}\text { Table 5. Sociodemographic Risk Factors Associated with } \\
\qquad \text { CSOM }(n=38)\end{array}$} \\
\hline
\end{tabular}

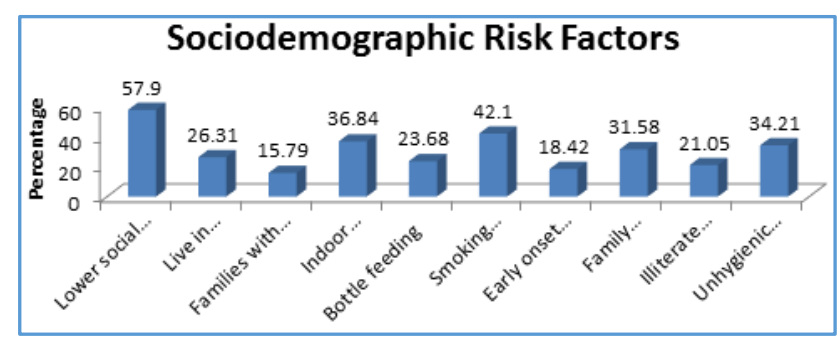

\begin{tabular}{|c|c|c|}
\hline Associated Factors & No. of Cases & \%age \\
\hline Upper respiratory infection & 12 & 31.58 \\
\hline Nasal allergy & 6 & 15.79 \\
\hline Chronic tonsillitis & 11 & 28.95 \\
\hline DNS & 8 & 21.05 \\
\hline Sinusitis & 7 & 18.42 \\
\hline Malnutrition & 20 & 52.63 \\
\hline Adenoid hypertrophy & 10 & 26.31 \\
\hline Persistent rhinorrhoea (>15 days) & 2 & 5.26 \\
\hline
\end{tabular}

Table 6. Clinical Risk Factors Associated with CSOM ( $\mathrm{N}=38)$

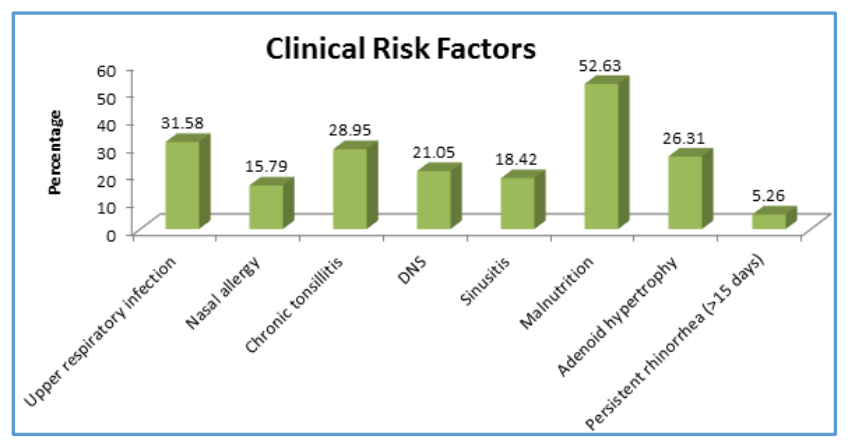

\section{DISCUSSION}

CSOM is one of the common diseases of the ear, particularly seen in childhood. Poor living conditions, overcrowding, poor hygiene, and nutrition have been suggested as causes for the widespread prevalence of CSOM in developing countries. It is more common in children of rural community where proper health facilities are lacking.

In this study, the prevalence of CSOM was found to be $1.41 \%$ in the urban schoolchildren and $5.45 \%$ in the rural schoolchildren, the difference being statistically significant. Okeowo ${ }^{[8]}$ reported a statistically significant difference in the prevalence of CSOM among the rural schoolchildren (3.6\%) and urban schoolchildren (0.6\%). Minja and Machemba ${ }^{[9]}$ found the prevalence of CSOM to be $9.4 \%$ among rural schoolchildren and $1.3 \%$ among urban schoolchildren in Dar es Salaam, Tanzania, the difference being statistically significant $(p<0.001)$. Rupa et al.[10] found the overall prevalence rate to be $6 \%$ among rural South Indian children. Ologe and Nwawolo[11] in their study of CSOM in schoolchildren in Nigeria found the prevalence to be $6.0 \%$ in a rural government primary school whereas that of $0 \%$ in a urban private school. Kamal et al.[12] in their study of children of slum dwellers in Dhaka city found the prevalence of CSOM to be $7.39 \%$. Adhikariet al.[13] in their cross-sectional study among schoolchildren of Kathmandu valley found the prevalence to be $5.7 \%$ in a government school and $4.8 \%$ in a urban school.

The difference reported in the prevalence of CSOM between urban and rural schoolchildren is statistically significant in most of the earlier studies, which can be attributed to the following factors prevalent in different populations-

- Low socioeconomic status.

- Low level of literacy.

- Lack of health consciousness.

- Inability to approach proper medical care.

- Malnutrition and poor living conditions.

- Swimming in dirty ponds, etc.

In our study, the duration of discharge in most of the CSOM cases in rural areas was $>3$ years $(25 \%)$ and 2 years $(28.57 \%)$ whereas that in the urban cases was 2 years $(50 \%)$. The findings of these studies were compared with those of studies conducted by different authors, which point to longstanding history of ear discharge in most cases.[14,15] In our study, the prevalence of unilateral disease with central perforation was more common compared to that of bilateral disease. This is in agreement with that reported in the existing literature. The prevalence of unilateral disease is believed to be good as it proffers a better prognosis in limiting the risk of disability from accompanying hearing loss than for bilateral disease. In our study, unilateral disease was found among $78.95 \%$ subjects, which was in-between the rates reported by Maharjan et al (67.24\%) and Adhikari et al (81.5\%). In this study, 36.8\% children had active disease, which was in-between the findings of Adhikari[16](26\%) and Adhikari[17] (38.6\%). This was because generally parents start medication from private practitioners in the form of antibiotics and eardrops, which provides temporary relief. Our study could not find the cases with CSOM complications as majority of cases were of tubotympanic type, which is considered to be a safe type. In our study, $86.84 \%$ schoolchildren had a tubotympanic type, which was inbetween the findings of Kamal et al (73.4\%) and Ologe and Nwawolo (99\%). This was due to the prevalence of tubotympanic-type CSOM. In our study, on performing tuning fork tests, it was found that $71.74 \%$ cases had conductive hearing loss and $2.17 \%$ had sensorineural hearing loss whereas $15.22 \%$ had normal test results. On pure tone audiometry testing, it was found that 38 cases (82.60\%) had conductive hearing loss whereas 3 cases $(6.52 \%)$ had mixed 
hearing loss and 2 cases $(2.17 \%)$ had sensorineural hearing loss whereas 4 cases $(8.70 \%)$ had hearing within normal range. The findings are compared with other studies done by Lasisi et al (2007) ${ }^{[18]}$ and Olatoke et al (2008).[19]

The important sociodemographic risk factors associated with CSOM in our study were lower socioeconomic status, living in congested houses, smoking habit of the father, indoor cooking, unhygienic ear cleaning practices, and family history of ear discharge. The important clinical risk factors associated with CSOM in our study were malnutrition, URI, chronic tonsillitis, and adenoid hypertrophy. This corresponds well with those reported in other studies carried out by different authors.[14,12,18,20,21-23]

Children from lower socioeconomic groups, being more vulnerable to otitis media, should be given special care to prevent hearing retardation. Swimming in polluted water of a pond or river regularly may be a factor responsible for discharging ear. Untreated acute suppurative otitis media can also persist as CSOM. Malnutrition and poor living conditions are more likely to prevail among rural schoolchildren. Poor housing was recognised as a risk factor for CSOM by WHO/CIBA Foundation Workshop conducted in 1996. Potential hearing loss because of otitis media has significant consequences on the development of speech and cognitive abilities, including academic performance of children. Thus, the gap between the fortunate and the less privileged is further widened by an innate difficulty in learning occasioned by CSOM.

The primary health-care programmes in remote communities should: (i) support strategies that reduce the transmission of bacterial infections to infants and toddlers; (ii) encourage timely immunisation; (iii) give advice on effective communication strategies for hearing-impaired children; (iv) provide early, frequent, and accurate assessment of middle ear disease in the first 18 months of life; (v) educate families regarding the improvement of socioeconomic status and appropriate management for different types of ear diseases; and (vi) help families and provide proper antibiotic treatment to their children with persistent suppurative otitis media. Health education through school health programme should be provided to prevent ear diseases, which is one of the major causes of deafness. Health education is the need of the hour for reducing the prevalence of CSOM and preventing hearing disability due to ear diseases among schoolchildren. Improvement of health-care facilities in rural, urban, and urban slum areas will be helpful in reducing the prevalence of CSOM.

\section{CONCLUSION}

This study shows that the prevalence of CSOM is higher in rural schoolchildren than that in urban schoolchildren. To conclude, it can be said that CSOM is still an important cause of morbidity. Health education through school health programme to prevent ear diseases, which is one of the major causes of deafness, is required to reduce the prevalence and prevent disability among schoolchildren. Improvement in socioeconomic status and health-care facilities is also helpful in reducing the prevalence of CSOM. School-based study could be one of the useful and cost-effective modalities aimed at launching a community-oriented programme. Creating awareness among the rural community against the ear disease through teachers, guardians, students and community health workers, and motivating the rural community to visit the nearest health-care facility for any ear-related problems in future.

\section{REFERENCES}

[1] Healy GB. Otitis media and middle ear effusions. In: Ballenger JJ. The ear, Williams and Williams. Baltimore 1996:1003-9.

[2] Seely DR, Gloyd SS, Wright AD, et al. Hearing loss prevalence and risk factors among Sierra Leonean children. Arch Otolaryngol Head Neck Surg 1995;121(8):853-8.

[3] Bluestone CB, Klein JO. Epidemiology, otitis media in infants and children. WB Saunders, Philadelphia 2001:58-78.

[4] Maharjan M, Bhandari S, Singh I, et al. Prevalence of otitis media in school going children in Eastern Nepal. Kathmandu Univ Med J 2006;4(4):479-82.

[5] Mawson SR. Diseases of the ear. $3^{\text {rd }}$ edn. Edward Arnold, London 1974:343-8.

[6] WHO/CIBA foundation workshop. Prevention of hearing impairment from chronic otitis media. WHO/ PDH/98.4. London: CIBA foundation, 1996.

[7] Verma AK, Vohra A, Maitra A, et al. Epidemiology of chronic suppurative otitis media and deafness in a rural area and developing an intervention strategy. Indian J Pediatr 1995;62(6):725-9.

[8] Okeowo PA. Observations on the incidence of secretory otitis media in Nigerian children. J Trop Pediatr 1985;31(6):295-8.

[9] Minja BM, Machemba A. Prevalence of otitis media, hearing impairment and children impaction among school children in rural and urban Dar es Salaam, Tanzania. Int J Pediatr Otorhinolaryngol 1996;37(1):29-34.

[10] Rupa V, Jacob A, Joseph A. Chronic suppurative otitis media: prevalence and practice among rural south Indian children. Int J Pediatr Otorhinloryngol 1999;48(3):217-21.

[11] Ologe FE, Nwawolo CC. Prevalence of chronic suppurative otitis media among school children in a rural community in Nigeria. Niger Postgrad Med J 2002;9(2):63-6.

[12] Kamal N, Joarder AH, Chowdhury AA, et al. Prevalence of chronic suppurative otitis media among the children living in two selected slums of Dhaka city. Bangladesh Med Res Counc Bull 2004;30(3):95-104.

[13] Adhikari P, Sinha BK, Pokharel NR, et al. Prevalence of chronic suppurative otitis media in school children of Kathmandu district. J Inst Med 2007;29(3)10-12.

[14] Melaku A, Lulseged S. Chronic suppurative otitis media in a children's hospital in Addis Ababa, Ethiopia. Ethiop Med J 1999;37(4):237-46.

[15] Biswas AC, Joarder AH, Siddhiquee BH. Prevalence of CSOM among rural school going children. Mymensingh Med J 2005;14(2):152-5.

[16] Adhikari P. Chronic suppurative otitis media in school children of Kathmandu valley. Int Arch Otorhinol 2007;11(2).

[17] Adhikari P. Prevalence of chronic suppurative otitis media in Nepalese children: experience of free health camps. Internet J Otorhinolaryngol 2008;10(2). 
[18] Lasisi AO, Sulaiman OA, Afolabi OA. Socio-economic status and hearing loss in chronic suppurative otitis media in Nigeria. Ann Trop Paediatr 2007;27(4):2916.

[19] Olatoke F, Ologe FE, Nwawolo CC, et al. The prevalence of hearing loss among schoolchildren with chronic suppurative otitis media in Nigeria, and its effect on academic performance. Ear Nose Throat J 2008;87(12):E19.

[20] Fliss DM, Shoham I, Leiberman A, et al. Chronic suppurative otitis media without cholesteatoma in children in southern Israel: incidence and risk factors. Pediatr Infect Dis J 1991;10(12):895-9.
[21] Bluestone CD. Epidemiology and pathogenesis of chronic suppurative otitis media: implications for prevention and treatment. Int J Pediatr Otorhinolaryngol 1998;42(3):207-23.

[22] Bandyopadhyay R, Sengupta A, Dasgupta A, et al. A comparative study of common ear morbidity patter among the primary school children of an urban slum of Kolkata and rural area of Hooghly. J Indian Med Assoc 2005;103(8):430-2.

[23] Erwin LVV, Schilder AG, Heerbeek NV, et al. Predictors of chronic suppurative otitis media in children. Arch Otolaryngol Head Neck Surg 2006;132(10):1115-8. 